\title{
An overview of efficacy and safety of ambroxol for the treatment of acute and chronic respiratory diseases with a special regard to children
}

\author{
Ahmad Kantar, ${ }^{1}$ Ludger Klimek, ${ }^{2}$ Dorotheea Cazan, ${ }^{3}$ Annette Sperl, ${ }^{2}$ Ulrike Sent, ${ }^{4}$ Margarida Mesquita $^{5}$ \\ ${ }^{1}$ Pediatric Cough and Asthma Center, Istituti Ospedalieri Bergamaschi, University and Research Hospitals, Bergamo, Italy \\ ${ }^{2}$ Wiesbaden Center for Rhinology and Allergology, Wiesbaden, Germany \\ ${ }^{3}$ Maria Hilf Kliniken, Department of Otorhinolaryngology, Head and Neck Surgery, University Hospital Aachen, \\ Mönchengladbach, Germany \\ ${ }^{4}$ Medical Advisor CHC GSA, Sanofi-Aventis Deutschland GmbH, Frankfurt am Main, Germany \\ ${ }^{5}$ Global Medical Lead CHC, Sanofi-Aventis Deutschland GmbH, Frankfurt am Main, Germany
}

Introduction: Ambroxol (2-amino-3,5-dibromo-N-[trans-4-hydroxycyclohexyl]benzylamine), an over-the-counter product, is a mucoactive agent and has been used widely to treat both acute and chronic respiratory diseases since 1978. This review aims to provide an overview of the clinical evidence available on the use of ambroxol in children with acute and chronic respiratory diseases. Data for this review were obtained from both published and unpublished clinical studies, and real-world evidence studies. Although conducted prior to the introduction of Good Clinical Practice (GCP), these studies, representing almost 1,300 pediatric patients, report strong clinical outcomes following the use of ambroxol in pediatric patients. Furthermore, efficacy findings were consistent irrespective of age, including for patients as young as 1 month old. Additionally, the majority of studies found ambroxol to be well tolerated in children. Taken together, the clinical evidence for ambroxol shows treatment effects that offer significant benefits to pediatric patients for its licensed use as a secretolytic therapy in acute and chronic bronchopulmonary disorders associated with abnormal mucus secretion and impaired mucus transport. The findings from this review indicate that ambroxol, for its intended over-the-counter indications, is both efficacious and well tolerated in children and that the favorable benefit/risk profile of ambroxol reported in adults extends to the pediatric population, starting from early infancy, with acute and chronic respiratory diseases.

Key words: Ambroxol; children; respiratory diseases; mucoactive; over-the-counter drugs.

Correspondence: Margarida Mesquita, Global Medical Lead CHC, Sanofi Aventis Deutschland GmbH, Industriepark Höchst, Building K607, Room 5007, 65926 Frankfurt am Main, Germany. E-mail: margarida.mesquita@sanofi.com

Contributions: All authors contributed to the preparation of this paper, including the development of the outline, review of all drafts, final approval and the decision to submit to Multidisciplinary Respiratory Medicine. All authors read and approved the final manuscript.

Conflict of interest: AK has acted as an advisor on the study design of an unlicensed product for Merck USA, as an advisor on the study design for trials on acute cough in adults and children for Sanofi Germany and Infirst Healthcare Ltd UK. LK has received research grants from ALK-Abelló, Denmark; Allergopharma, Germany; Bionorica, Germany; Biomay, Austria; Boehringer Ingelheim, Germany; Circassia, USA; Stallergenes, France; Sanofi, Germany; HAL, Netherlands; Allergy Therapeutics/Bencard, Great Britain/Germany; Hartington, Spain; Lofarma, Italy; MEDA, Sweden; MSD, USA; Novartis, Switzerland; Leti, Spain; ROXALL, Germany; GSK, Great Britain; Cytos, Switzerland; Curalogic, Denmark; and/or has served as a consultant or on the speaker's bureau for the above mentioned pharmaceutical companies. DC and AS report no conflicts of interest. US and MM are employees of Sanofi-Aventis. AK is a member of the Editorial Board of Multidisciplinary Respiratory Medicine.

Funding: This research did not receive any specific grant from funding agencies in the public, commercial, or not-for-profit sectors.

Availability of data and materials: Qualified researchers may request access to patient level data and related study documents including the clinical study report, study protocol with any amendments, blank case report form, statistical analysis plan, and dataset specifications. Patient level data will be anonymized and study documents will be redacted to protect the privacy of trial participants. Further details on Sanofi's data sharing criteria, eligible studies, and process for requesting access can be found at: https://www.clinicalstudydatarequest.com 


\section{Introduction}

Acute cough is a common ailment for which patients seek medical advice, accounting for $>50 \%$ of new patient attendance in primary care settings [1]. Common cold or acute bronchitis frequently result in acute cough; however, distinguishing between causes is often difficult [2]. Although considered a self-limiting disease, acute cough poses a high symptom burden, particularly to children, in whom symptoms last an average of 25 days [3]. A daily cough lasting $>4$ weeks in children is considered chronic [4]. Overthe-counter (OTC) cough medicines are the first-line treatment for acute cough and are frequently self-prescribed by patients or their carers [5]. These medicines vary in their mechanisms of action depending on their active ingredients, and include antitussives, antihistamines (with or without decongestants) and mucoactive agents [6].

Mucoactive agents alter the viscoelastic properties of mucus and promote mucociliary clearance, and can be categorized into groups according to their mechanisms of action, including expectorants, mucoregulators, mucolytics and mucokinetics [7]. Ambroxol (2-amino-3,5-dibromo- $N$-[trans-4-hydroxycyclohexyl] benzylamine) is considered a mucoactive agent and has been widely used to treat acute and chronic respiratory diseases since 1978 [8]. Similar to its parent compound bromhexine [9], ambroxol has both mucokinetic and mucociliary effects as shown in clinical studies with adult patients with respiratory disease [10]. Moreover, structural differences with bromhexine, such as the presence of a hydroxyl group in a para-trans position of the cyclohexyl ring and the deletion of a methyl group, have provided ambroxol with additional pharmacological properties, including stimulation of surfactant production, anti-inflammatory activity, anti-oxidant action and local anesthetic effects [10].

Ambroxol is available in multiple formulations, including lozenges, intramuscular and intravenous solutions, syrup, granules, tablets, slow-release oral formulations and nebulized solutions [11]. For the treatment of children with acute and chronic respiratory diseases associated with abnormal mucus secretion and impaired mucus transport, ambroxol is available OTC as a syrup. Other authorized indications of ambroxol include prophylaxis and treatment of postoperative bronchopulmonary complications, pain relief in acute sore throat (adults and children $>12$ years), and prophylaxis and treatment of infant respiratory distress syndrome (IRDS) [8]. A study by Zhang et al. reported that, in cases of inevitable preterm birth, antenatal ambroxol is recommended over corticosteroids to prevent neonatal respiratory distress syndrome (RDS) [12], demonstrating how ambroxol has been safely and effectively used to treat infants.

The present review aims to provide an overview of the clinical evidence available on the use of ambroxol in children and infants. Data for this review were obtained from both published and unpublished clinical studies on ambroxol in children with acute and chronic respiratory diseases; these were provided to the European Medicines Agency's Pharmacovigilance Risk Assessment Committee (PRAC) by the marketing authorization holder (Sanofi-Aventis) in 2014 as part of a benefit/risk assessment of ambroxol-containing medicines. Additionally, real world evidence (RWE) data were included from more recently published pharmacy-based surveys and cohort studies. In this article, we evaluate the clinical evidence of ambroxol in children, covering the full pediatric age range (0-12 years) for which the product is indicated. Where available, data for younger children (0-6 years) and older children (6-12 years) are discussed separately. In addition, we summarize the pharmacokinetics of ambroxol and its mechanism of action in terms of its indications in the OTC setting.
Overall, we present data (published and unpublished) from six controlled and four uncontrolled clinical studies, comprising a total of 1,274 pediatric patients, as well as RWE data from pharmacybased surveys and cohort studies, representing 3,629 patients (including children).

\section{Pharmacokinetics}

The pharmacokinetics of ambroxol have recently been reviewed in detail in Cazan et al. [13]. Ambroxol has a bioavailability of $79 \%$ when administered orally [10]. It is metabolized in the liver by cytochrome P450 3A4 and has a terminal elimination half-life of approximately $10 \mathrm{~h}$, with a total clearance of 660 $\mathrm{ml} / \mathrm{min}[10,14]$. On distribution from blood to tissue, the highest concentration of ambroxol is found in the lungs; in human lung tissue, ambroxol has been detected at concentrations 15- to 20-fold higher than those in the blood [13]. Furthermore, age and gender have not been shown to affect the pharmacokinetics of ambroxol to a clinically relevant extent, therefore dose adjustment is not indicated [14].

\section{Mechanisms of action}

The main mechanism of action for ambroxol involves stimulation of surfactant synthesis, a complex mechanism that is not yet fully understood [15], but that gives ambroxol effective mucokinetic and secretagogue properties, thus promoting mucous clearance, facilitating expectoration and easing productive cough. In addition to the mucokinetic and secretagogue properties, ambroxol is also known to have numerous widespread pharmacodynamic properties (Figure 1) [11]. Ambroxol accumulates in lamellar bodies, secretory lysosomes of type II pneumocytes that store surfactant, where it affects hydrogen and calcium ion homeostasis. Here, it leads to loss of lamella, inducing changes in the nanostructural assembly of surfactant layers [16]. This results in the synthesis and release of surfactant by type II pneumocytes [8]. Surfactant plays an important role in upper and lower airway functions. Firstly, surfactant reduces surface tension in the alveoli, preventing their collapse [17]. This is particularly relevant for ambroxol's use in infants with RDS [8]. It is also known that surfactant decreases mucous viscosity through depolymerization of acidic polysaccharide fibers in the bronchial secretion and stimulation of neutral polysaccharide production by glandular cells [8]. In addition to these actions, surfactant aids cough clearance by separating the periciliary and gel layers of airway mucus, and reducing mucus adherence to the airway epithelium $[17,18]$. In animal models, ambroxol has also been reported to increase mucociliary clearance

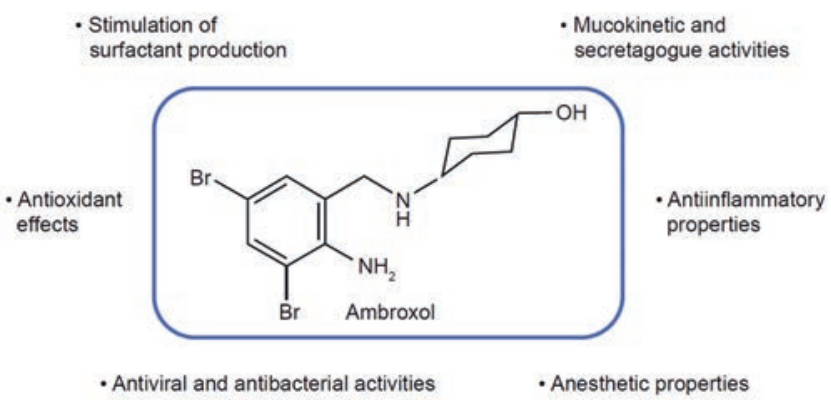

Figure 1. Representation of known pharmacodynamic properties of ambroxol. From Paleari et al., Expert Opin Drug Discov 2011;6:1203-14 [11]; with permission. 
by increasing ciliary beat frequency [19].

In addition to its secretolytic and mucokinetic effects, ambroxol exerts antioxidant properties through direct scavenging and protection from reactive oxygen species, anti-inflammatory properties by inhibiting leukocytes from secreting pro-inflammatory mediators, and local anesthetic properties via inhibition of neuronal sodium channels, producing a possible antitussive effect [11,20,21]. Additionally, due to an increased number of substances that suppress viral replication and affect bacterial biofilm structures, including immunoglobulins A and G, ambroxol has also been associated with a protective effect against viral and bacterial airway infections $[22,23]$. Ambroxol is also believed to act synergistically with antibiotics by increasing the concentration of antibiotics in the lungs when co-administered [24].

Furthermore, this synergistic relationship is believed to be a result of surfactant stimulation. This hypothesis is supported in a study by Basabe-Burgos [25] in which polymyxin E, administered together with poractant alfa (animal-derived surfactant), reduced bacterial load in the lungs more than polymixin E alone [25]. This may have been a result of more efficient spreading of polymyxin E, mediated by the surfactant, as pulmonary surfactant spreads rapidly over the airway epithelium [25]. A similar mechanism may therefore be postulated for ambroxol, given it enhances surfactant production.

\section{Brief overview of efficacy and safety of ambroxol in adults}

The efficacy and safety of ambroxol in the treatment of airway diseases has recently been evaluated for adults in a review by Cazan et al. [13]. This review concluded that the benefit/risk profile of ambroxol is favorable in adult patients, with a number of clinical studies reporting that ambroxol improved respiratory symptoms and prevented acute exacerbations [13]. In terms of the safety of ambroxol in adult populations, gastrointestinal disturbances were the most commonly experienced adverse events (AEs) following ambroxol treatment, but rarely led to discontinuation [13]. Additionally, most AEs reported were mild and selflimiting, such as insomnia, cutaneous rash, vomiting and abdominal pain [13]. Following this review, it was deemed important to highlight the robustness of the available clinical data, and make evident the efficacy and safety of ambroxol in children, starting from early infancy, with respiratory disease.

\section{Efficacy and safety of ambroxol in children}

\section{Included studies}

As with most studies on mucoactive substances, the research focusing on the efficacy and safety of ambroxol in children was mostly conducted before Good Clinical Practice (GCP), the international, ethical and scientific quality standards required when conducting all clinical trials, and that came into effect in 1997 [26]; however, the majority of studies included in this review used wellrecognized methodologies, as indicated by the consistency between study endpoints, and can be considered to be of sufficient quality.

In this review, we present data (published and unpublished) from six controlled and four uncontrolled clinical studies, comprising a total of 1,274 pediatric patients, as well as RWE data from pharmacy-based surveys and cohort studies, representing 3,629 patients (including children). The indications of ambroxol across these studies included acute and chronic respiratory diseases. Table 1 (controlled studies), Table 2 (uncontrolled studies) and Table 3 (RWE studies) provide the details of each study presented in this review.

\section{Efficacy overview}

\section{Controlled clinical studies}

\section{Randomized placebo-controlled studies}

A randomized, double-blind, placebo-controlled study by Principi et al. [27] assessed the efficacy of ambroxol syrup as an adjuvant to antibiotic treatment in 120 children aged 1 month-11 years with acute bacterial pneumonia [27]. In total, 60 children received ambroxol for 7-10 days; children aged 1 month-2 years, 2-5 years and $>5$ years, received $2.0,1.7$ and $1.5 \mathrm{mg} / \mathrm{kg}$, respectively [27]. Efficacy assessments included daily fever, cough, dyspnea, pathological auscultatory signs and highest temperature. Radiological examinations were also performed before treatment and at the end of the study [27]. By the end of treatment, all children had a normal body temperature and heart and respiratory rate, and no cough or dyspnea present, irrespective of receiving ambroxol or placebo [27]. However, from day 3 onwards, cough was reduced significantly faster in children treated with ambroxol compared with placebo $(\mathrm{p}<0.05)$ and from day 4 , pathological auscultatory signs improved significantly more with ambroxol treatment compared with placebo $(\mathrm{p}<0.05)$ [27]. Additionally, pretreatment radiological findings were normalized in $79 \%$ of children receiving ambroxol compared with only $53 \%$ in the placebo group $(\mathrm{p}<0.01)$ [27].

\section{Randomized active-controlled studies}

A randomized study by Careddu and Zavattini [28], involving 60 children aged 2-12 years with acute respiratory diseases (including bronchitis, asthmatic bronchitis and tracheobronchitis), compared the efficacy of ambroxol and N-acetylcysteine (NAC). Some patients also received antibiotics [28]. In total, 29 children received ambroxol at a dosage of $45 \mathrm{mg}$ /day (children aged $\leq 4$ years) or $60 \mathrm{mg} /$ day (children aged $\geq 5$ years) for 6-8 days. Sputum characteristics, severity and frequency of cough and discomfort caused by catarrh were used to assess the efficacy of ambroxol. Maximal expiratory flow at $25 \%$ of forced vital capacity $\left(\mathrm{MEF}_{25}\right)$, forced expiratory volume in one second $\left(\mathrm{FEV}_{1}\right)$ and total airway resistance $\left(R_{\text {awt }}\right)$ were also measured in some patients [28]. Both treatments significantly decreased sputum viscosity $(p<0.001)$ and sputum volume decreased to 0 (not present) by the end of treatment. Significant changes were also seen in $\mathrm{MEF}_{25}(\mathrm{p}<0.001)$, $\mathrm{FEV}_{1}(\mathrm{p}<0.001)$ and $\mathrm{R}_{\text {awt }}(\mathrm{p}<0.001)$ in both treatment groups between the start and end of treatment. By day 4, significantly greater improvements in the severity and frequency of cough and discomfort caused by catarrh were reported in the ambroxol group compared with the NAC group $(p<0.001)$ [28]. Based on these improvements, treatment efficacy was rated by physicians as favorable in $100 \%$ of the patients receiving ambroxol compared with $68 \%$ receiving NAC $(\mathrm{p}<0.01)$, leading the authors to conclude that the efficacy of ambroxol exceeds that of NAC. Furthermore, efficacy was consistent between age groups [28].

A randomized, open-label study by Berni et al. [29] compared the efficacy of ambroxol and carbocysteine/S-carboxymethyl cysteine $(\mathrm{SCMC})$ in 30 children aged 2-8 years with acute bronchopulmonary diseases, such as bronchitis and pharyngotracheobronchitis [29]. Ambroxol was administered to 15 children at a dosage of $45 \mathrm{mg}$ /day (aged $\leq 5$ years) or $60 \mathrm{mg} /$ day (aged $>5$ years) for 2-14 days. Some children also received antibiotics [29]. The efficacy of ambroxol was measured by changes in expectoration, cough, dyspnea and auscultatory signs [29]. Most cases of dyspnea resolved by day 2, except for one case in the SCMC group which 
Table 1. Characteristics and results of controlled studies of ambroxol in acute and chronic respiratory diseases in pediatric patients.

\begin{tabular}{|c|c|c|c|}
\hline Study & $\begin{array}{l}\text { Study design } \\
\text { and aim }\end{array}$ & $\begin{array}{l}\text { Patient demographics } \\
\text { and disease } \\
\text { characteristics }\end{array}$ & $\begin{array}{l}\text { Number of patients; } \\
\text { ambroxol treatment } \\
\text { dosage and duration }\end{array}$ \\
\hline $\begin{array}{l}\text { Principi } \\
\text { et al. } \\
{[27]}\end{array}$ & $\begin{array}{l}\text { Double-blind, } \\
\text { placebo controlled, } \\
\text { randomized study } \\
\text { to assess the } \\
\text { efficacy of ambroxol } \\
\text { as an adjuvant to } \\
\text { antibiotic treatment }\end{array}$ & $\begin{array}{l}\text { Patients aged } 1 \\
\text { month-1l years } \\
\text { with acute infections } \\
\text { of the lower respiratory } \\
\text { tract, i.e. bacterial } \\
\text { pneumonia }\end{array}$ & $\begin{array}{l}\text { - } 120 \text { patients received } \\
\text { treatment daily for } 7-10 \text { days } \\
\text { - } 60 \text { patients received ambroxo } \\
\text { [2.0 mg/kg (1 month-2 years), } \\
1.7 \mathrm{mg} / \mathrm{kg}(2-5 \text { years), } \\
\text { or } 1.5 \mathrm{mg} / \mathrm{kg}(>5 \text { years)] } \\
\text { - } 60 \text { patients received placebo } \\
\text { - Administered as a syrup } \\
\text { - } 82 \text { patients aged } \leq 5 \text { years } \\
\text { and } 38 \text { patients aged between } \\
6 \text { and } \leq 12 \text { years }\end{array}$ \\
\hline
\end{tabular}

Study
parameters
- Fever, cough, dyspnea,
pathological auscultatory
signs and highest
daily temperature
recorded daily
- Radiological examinations
and laboratory tests
performed before
treatment and at
the end of the study

$\begin{array}{ll}\text { Efficacy } & \text { Safety } \\ \text { results } & \text { results }\end{array}$

Cough was reduced significantly faster in patients treated with ambroxol than those treated with placebo from day 3 onwards $(\mathrm{p}<0.05)$

- Thoracic symptoms

improved significantly

(from day 4) with

ambroxol treatment compared with placebo $(p<0.05)$

- Pre-treatment radiological findings were normalized in $79 \%$ of patients in the ambroxol group compared with $53 \%$ in the placebo group $(\mathrm{p}<0.01)$

- Ambroxol and antibiotic co-treatment resulted in faster symptomatic relief from mucostasis than treatment with antibiotics alone

\begin{tabular}{|c|c|c|c|c|c|c|}
\hline $\begin{array}{l}\text { Baldini } \\
\text { et al. } \\
{[30]}\end{array}$ & $\begin{array}{l}\text { Controlled clinical } \\
\text { study to compare } \\
\text { the efficacy and safety } \\
\text { of ambroxol compared } \\
\text { and N-acetylcysteine } \\
\text { (NAC) }\end{array}$ & $\begin{array}{l}\text { Patients aged 2-13 } \\
\text { years with spastic } \\
\text { bronchitis } \\
\text { (acute bronchial disease) }\end{array}$ & $\begin{array}{l}\text { - } 28 \text { patients received treatment } \\
\text { for } 10 \text { days } \\
-14 \text { patients received ambroxol } \\
30 \mathrm{mg} \\
-14 \text { patients received } \\
\text { NAC } 200-300 \mathrm{mg} / \text { day } \\
\text { - Administered orally (sachets) } \\
-8 \text { patients were aged } \leq 5 \text { years } \\
\text { and } 20 \text { patients were aged } \\
\text { between } 6 \text { and } \leq 12 \text { years }\end{array}$ & $\begin{array}{l}\text { - Main signs and symptoms - } \\
\text { of bronchial disease } \\
\text { recorded at the start of } \\
\text { treatment, on day } 5 \\
\text { and at the end of treatment, } \\
\text { including: sputum } \\
\text { quantity and viscosity, } \\
\text { dyspnea and bronchial } \\
\text { sounds, and difficulty } \\
\text { expectorating sputum } \\
\text { - Respiratory function, } \\
\text { including FVC, FEVl } \\
\text { and PEF, recorded in } \\
\text { cooperative patients } \\
\text { at the start and end } \\
\text { of treatment } \\
\text { - Common laboratory tests } \\
\text { performed at the start and } \\
\text { end of treatment, including } \\
\text { complete blood count, blood } \\
\text { nitrogen, blood glucose, } \\
\text { transaminase and total proteins } \\
\text { - Adverse events were recorded } \\
\text { throughout the study }\end{array}$ & $\begin{array}{l}\text { Both treatments improved } \\
\text { symptoms and sputum } \\
\text { characteristics } \\
\text { By day } 5 \text {, greater } \\
\text { improvements } \\
\text { in bronchial symptoms } \\
\text { were reported } \\
\text { for ambroxol } \\
\text { treatment than } \\
\text { NAC treatment } \\
\text { Improvements were } \\
\text { identical by study } \\
\text { completion } \\
\text { Changes in dyspnea were } \\
\text { significantly greater in } \\
\text { the ambroxol group compared } \\
\text { with the NAC group }(p<0.05)\end{array}$ & $\begin{array}{l}\text { No adverse changes } \\
\text { in laboratory } \\
\text { results and } \\
\text { no notable } \\
\text { side effects occurred } \\
\text { in either treatment } \\
\text { group }\end{array}$ \\
\hline $\begin{array}{l}\text { Berni } \\
\text { et al. } \\
{[29]}\end{array}$ & $\begin{array}{l}\text { Randomized, } \\
\text { open-label } \\
\text { study to compare } \\
\text { the efficacy of } \\
\text { ambroxol with } \\
\text { carbocysteine/ } \\
\text { S-carboxylmethyl } \\
\text { cysteine (SCMC), } \\
\text { with or without } \\
\text { antibiotics }\end{array}$ & $\begin{array}{l}\text { Patients aged 2-8 } \\
\text { years with acute } \\
\text { bronchial } \\
\text { diseases }\end{array}$ & $\begin{array}{l}-30 \text { patients received } \\
\text { treatment daily for } \\
2-14 \text { days } \\
\text { (average treatment } \\
\text { duration of } 8 \text { days) } \\
\text { - } 15 \text { patients received } \\
\text { ambroxol (45 m/day in } \\
\text { patients } \leq 5 \text { years; } \\
60 \mathrm{mg} / \text { day in patients } \\
>5 \text { years) } \\
-15 \text { patients received SCMC } \\
\text { (200 mg/day in patients } \\
\leq 5 \text { years old; } 300 \mathrm{mg} / \text { day } \\
\text { in patients }>5 \text { years old) } \\
\text { Administered as syrup }\end{array}$ & $\begin{array}{l}\text { - Changes in expectoration, - } \\
\text { cough, dyspnea, thorax X-ray } \\
\text { and other pathological } \\
\text { observations } \\
\text { - Adverse events were } \\
\text { recorded throughout } \\
\text { the study }\end{array}$ & $\begin{array}{l}\text { Most cases of dyspnea } \\
\text { resolved by day 2, except for one } \\
\text { case in the SCMC group which } \\
\text { resolved by day } 3 \\
\text { Both treatments significantly } \\
\text { improved expectoration } \\
\text { and severity of cough ( } \mathrm{p}<0.001 \text { ); } \\
\text { however, improvements in these } \\
\text { symptoms occurred more rapidly } \\
\text { with ambroxol (73.3\% free } \\
\text { of symptoms on day 3) compared } \\
\text { with SCMC ( } 46.6 \% \text { free } \\
\text { of symptoms on day 3) } \\
\text { Remission of auscultatory } \\
\text { signs was significant at day } 2 \\
\text { with ambroxol ( } p<0.02 \text { ) compared with } \\
\text { day } 6 \text { in the SCMC group ( }<<0.01 \text { ) } \\
\text { The investigator reported efficacy as } \\
\text { 'excellent' for 50\% of the ambroxol group } \\
\text { compared with 25\% for the SCMC } \\
\text { group and ‘g0od' for 50\% of the ambroxol } \\
\text { group compared with } 75 \% \text { of the SCMC grou }\end{array}$ & $\begin{array}{l}\text { Tolerability for both } \\
\text { treatments was } \\
\text { reported as excellent }\end{array}$ \\
\hline
\end{tabular}


Multidisciplinary Respiratory Medicine 2020; 15:511 - A. Kantar et al.

Table 1. Continued from previous page.

\begin{tabular}{|c|c|c|c|c|c|c|}
\hline Study & $\begin{array}{l}\text { Study design } \\
\text { and aim }\end{array}$ & $\begin{array}{l}\text { Patient demographics } \\
\text { and disease } \\
\text { characteristics }\end{array}$ & $\begin{array}{l}\text { Number of patients; } \\
\text { ambroxol treatment } \\
\text { dosage and duration }\end{array}$ & $\begin{array}{l}\text { Study } \\
\text { parameters }\end{array}$ & $\begin{array}{l}\text { Efficacy } \\
\text { results }\end{array}$ & $\begin{array}{l}\text { Safety } \\
\text { results }\end{array}$ \\
\hline $\begin{array}{l}\text { Careddu } \\
\text { and } \\
\text { Zavattini } \\
{[28]}\end{array}$ & $\begin{array}{l}\text { Randomized } \\
\text { study to compare } \\
\text { the efficacy } \\
\text { of ambroxol } \\
\text { with NAC, } \\
\text { with or without } \\
\text { antibiotics }\end{array}$ & $\begin{array}{l}\text { Patients aged 2-12 } \\
\text { years with acute } \\
\text { respiratory disease }\end{array}$ & $\begin{array}{l}\text { - } 60 \text { patients received } \\
\text { treatment daily } \\
\text { for } 6-8 \text { days } \\
\text { - } 29 \text { patients received } \\
\text { ambroxol daily } \\
\text { ( } 45 \mathrm{mg} \text { in patients aged } \\
\leq 4 \text { years; } 60 \mathrm{mg} \text { daily } \\
\text { in patients } \geq 5 \text { years of age) } \\
\text { - } 31 \text { patients received NAC } \\
\text { (600 mg daily) } \\
\text { - Administered as syrup - } \\
\text { (15 mg/5 ml) }\end{array}$ & $\begin{array}{l}\text { - Sputum characteristics } \\
\text { and clinical parameters, } \\
\text { including severity and } \\
\text { frequency of cough, } \\
\text { discomfort caused by } \\
\text { catarrh, pathological } \\
\text { auscultatory signs and } \\
\text { presence and extent } \\
\text { of dyspnea and cyanosis } \\
\text { - Lung function parameters, } \\
\text { including } \mathrm{MEF}_{25}, \mathrm{FEVl} \text { and Rawt, } \\
\text { along with } \mathrm{PaO} \text { and } \mathrm{PaCO}, \\
\text { measured in some patients } \\
\text { - Laboratory tests carried out } \\
\text { before and after the treatment } \\
\text { period, including } \mathrm{RBC}, \mathrm{WBC}, \mathrm{Hb}, \\
\text { ESR, BUN, blood glucose } \\
\text { and transaminase }\end{array}$ & 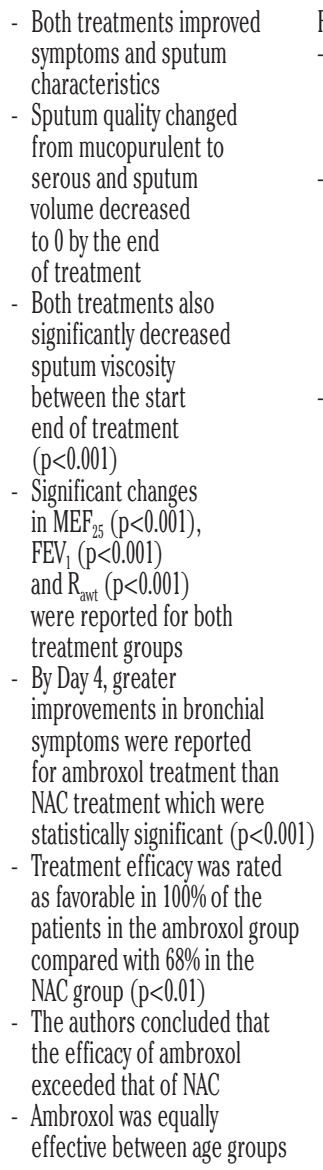 & $\begin{array}{l}\text { For both treatments: } \\
\text { - No side effects occurred } \\
\text { and tolerability was } \\
\text { rated as 'good' or 'excellent' } \\
\text { in all patients } \\
\text { - Systemic tolerability } \\
\text { was considered optimal } \\
\text { as no changes in laboratory } \\
\text { test results occurred } \\
\text { between the start and } \\
\text { end of treatment } \\
\text { in either group } \\
\text { - Well tolerated between } \\
\text { different age groups }\end{array}$ \\
\hline $\begin{array}{l}\text { Boehringer } \\
\text { Ingelheim } \\
\text { International } \\
\text { GmbH [31] }\end{array}$ & $\begin{array}{l}\text { Open-label } \\
\text { study to compare } \\
\text { the efficacy } \\
\text { of ambroxol and } \\
\text { sobrerol }\end{array}$ & $\begin{array}{l}\text { Patients aged } \\
1 \text { month-10 years } \\
\text { with bronchitis } \\
\text { and } \\
\text { bronchopneumonia }\end{array}$ & $\begin{array}{l}\text { - } 40 \text { patients received } \\
\text { treatment daily } \\
\text { - } 20 \text { subjects received } \\
\text { ambroxol [1.7 mg/kg } \\
\text { (<2 years), } 1.6 \mathrm{mg} / \mathrm{kg} \\
\text { (2-5 years) and } \\
1.2 \mathrm{mg} / \mathrm{kg} \text { (6-10 years)] } \\
\text { intramuscularly } \\
\text { - } 20 \text { patients received } \\
\text { soberol (1-2 vials } \\
\text { administered per day } \\
\text { as reference) }\end{array}$ & $\begin{array}{l}\text { - Bronchosecretolytic } \\
\text { effect (auscultatory } \\
\text { findings and cough) }\end{array}$ & $\begin{array}{l}\text { - Mean duration was } 7.5 \text { days } \\
\text { and } 7.9 \text { days for ambroxol } \\
\text { and soberol, respectively } \\
\text { - 'Excellent' efficacy was } \\
\text { reported in } 50 \% \text { of } \\
\text { the ambroxol group } \\
\text { compared with 45\% } \\
\text { of the sobrerol group } \\
\text { and 'good' efficacy } \\
\text { was reported in 40\% } \\
\text { of the ambroxol group compared } \\
\text { with 35\% of the sobrerol group }\end{array}$ & $\begin{array}{l}\text { - No side effects were } \\
\text { reported and tolerability } \\
\text { was rated as 'good' or } \\
\text { 'excellent' in all patients }\end{array}$ \\
\hline $\begin{array}{l}\text { Boehringer } \\
\text { Ingelheim } \\
\text { Internationa } \\
\text { GmbH [32] }\end{array}$ & $\begin{array}{l}\text { Follow-on study } \\
\text { to U86-0347 } \\
\text { to compare } \\
\text { the efficacy of } \\
\text { ambroxol } \\
\text { and sobrerol }\end{array}$ & $\begin{array}{l}\text { Patients aged } 1 \\
\text { month-12 years } \\
\text { with bronchitis } \\
\text { and bronchopneumonia }\end{array}$ & $\begin{array}{l}\text { - } 40 \text { patients received } \\
\text { treatment daily } \\
\text { - } 20 \text { patients received } \\
\text { ambroxol } \\
{[1.7 \mathrm{mg} / \mathrm{kg} \text { (<2 years), }} \\
1.6 \mathrm{mg} / \mathrm{kg} \text { ( } 2-5 \text { years) } \\
\text { and } 1.2 \mathrm{mg} / \mathrm{kg}(6-10 \text { years })] \\
\text { intramuscularly } \\
\text { - } 20 \text { patients received } \\
\text { soberol (1-2 vials administere } \\
\text { per day as reference) }\end{array}$ & - Bronchosecretolytic effect & $\begin{array}{l}\text { - Mean duration of } \\
\text { treatment was } 7.9 \text { days } \\
\text { in the ambroxol group } \\
\text { compared with } 8.3 \\
\text { in the sobrerol group } \\
\text { - The efficacy of ambroxol } \\
\text { was reported as 'excellent' } \\
\text { in } 65 \% \text { of the ambroxol group } \\
\text { compared with 25\% } \\
\text { in the sobrerol group and } \\
\text { 'good' in 25\% of the ambroxol } \\
\text { group compared with 45\% in the } \\
\text { sobrerol group }\end{array}$ & No side effects reported \\
\hline
\end{tabular}

BUN, blood urea nitrogen; ESR, erythrocyte sedimentation rate; $\mathrm{FV}$, forced vital capacity; FEVl, forced expiratory volume in 1 second; $\mathrm{Hb}$, hemoglobin; $\mathrm{MEF} 25$, maximal expiratory flow at 25\% of forced vital capacity; $\mathrm{NAC}^{\mathrm{N}} \mathrm{N}$-acetylcysteine; $\mathrm{PaO}{ }_{2,}$ partial pressure of oxygen; PaCO2, partial pressure of carbon dioxide; RBC, red blood cell; PEF, peak expiratory flow; Rawt, total airway resistance; SCMC, carbocysteine/S-carboxymethyl cysteine; WBC, white blood cell. 
Table 2. Characteristics and results of uncontrolled studies of ambroxol in acute and chronic respiratory diseases in pediatric patients.

\begin{tabular}{|c|c|c|c|c|c|}
\hline Study & $\begin{array}{l}\text { Study design } \\
\text { and aim }\end{array}$ & $\begin{array}{l}\text { Patient demographics } \\
\text { and disease } \\
\text { characteristics }\end{array}$ & $\begin{array}{l}\text { Number of patients; } \\
\text { ambroxol treatment } \\
\text { dosage and duration }\end{array}$ & $\begin{array}{l}\text { Study } \\
\text { parameters }\end{array}$ & $\begin{array}{l}\text { Efficacy } \\
\text { results }\end{array}$ \\
\hline $\begin{array}{l}\text { Weinmann } \\
\text { [33] }\end{array}$ & $\begin{array}{l}\text { Dose-response } \\
\text { study to determine } \\
\text { the benefittrisk } \\
\text { profile of different } \\
\text { formulations } \\
\text { of ambroxol }\end{array}$ & $\begin{array}{l}\text { Patients aged } \\
2 \text { months-15 years } \\
\text { with acute and } \\
\text { chronic airway diseases } \\
\text { (mainly bronchitis) }\end{array}$ & $\begin{array}{l}\text { - } 229 \text { patients received } \\
\text { ambroxol 'original } \\
\text { formulation' } \\
{[15-20 \mathrm{mg} / \text { day }} \\
\text { (<2 years), } \\
25-30 \mathrm{mg} / \text { day } \\
\text { (2-5 years), } \\
\text { or } 45 \mathrm{mg} / \text { day } \\
\text { (6-12 years)] } \\
\text { - } 111 \text { patients received } \\
\text { 'final formulation' } \\
{[15 \mathrm{mg} / \text { day ( } 22 \text { years), }} \\
\text { or } 30 \text { mg/day ( }>2 \text { years)] } \\
\text { - Administered as a syrup } \\
\text { - Some children also } \\
\text { received antibiotics } \\
\text { - } 51 \text { patients aged } \\
<2,81 \text { aged 2-5, } \\
95 \text { aged 6-12 for original } \\
\text { formulation; } 82 \text { patients } \\
\text { aged } 0-5 \text { and } 29 \text { aged } \\
\text { 6-12 for final formulation }\end{array}$ & $\begin{array}{l}\text { Cough and sputum } \\
\text { characteristics }\end{array}$ & $\begin{array}{l}\text { Original formulation: } \\
\text { - In children with sputum, } \\
\text { a mucolytic effect was reported } \\
\text { on day } 2 \text { or } 3 \text { of treatment } \\
\text { - Cough present at baseline improvec } \\
\text { or disappeared completely } \\
\text { in } 87 \% \text { of the patients by day } 7 \\
\text { - The benefitrisk profile of } \\
\text { ambroxol was reported } \\
\text { as highly favorable as, } \\
\text { in all age groups, symptoms } \\
\text { completely resolved or improved } \\
\text { after } 7 \text { days of treatment } \\
\text { Final formulation: } \\
\text { - Therapeutic effect of ambroxol } \\
\text { was evident in } 81 \% \text { of the children } \\
\text { after 2-3 days of treatment } \\
\text { - From day 3, there was a } \\
\text { substantial improvement } \\
\text { in sputum volume and, } \\
\text { by day 7, sputum and } \\
\text { dry cough were absent } \\
\text { in more than two thirds } \\
\text { of the children }\end{array}$ \\
\hline
\end{tabular}

Safety

results

- One patient receiving ambroxol in the form of tablets (the only patient to be treated

for 32 days who was also receiving antibiotics and corticosteroids) complained of a facial erythema on day 24-29 that was considered unrelated to ambroxol treatment by the investigator

- In the investigation involving ambroxol drops/inhalant solution, one patient (a 3-year-old boy) experienced 'frequent and severe' vomiting related to the method of administration of ambroxol rather than the treatment itself - Six patients (five aged 0-5 years, one aged 6 years) experienced side effects, including diarrhea, vomiting, rise in temperature, tachycardia, morbilliform exanthema and severe abdominal pains, after intramuscular injection of ambroxol. In two patients aged $0-5$ years, the events were considered unrelated to ambroxol treatment; in the remaining four patients, the relation between the events and treatment was considered unlikely

\begin{tabular}{|c|c|c|c|c|c|c|}
\hline $\begin{array}{l}\text { Boehringer } \\
\text { Ingelheim } \\
\text { International } \\
\text { GmbH [34] }\end{array}$ & $\begin{array}{l}\text { Open-label } \\
\text { multicenter } \\
\text { study to } \\
\text { evaluate } \\
\text { efficacy and } \\
\text { acceptance } \\
\text { of ambroxol }\end{array}$ & $\begin{array}{l}\text { Patients aged 0-12 years } \\
\text { with acute and chronic } \\
\text { upper respiratory tract } \\
\text { disorders } \\
\text { (mainly bronchitis) }\end{array}$ & $\begin{array}{l}\text { - } 137 \text { patients received } \\
\text { ambroxol for up to } 28 \\
\text { days according to the } \\
\text { recommended dosage } \\
\text { for their age group } \\
\text { and weight } \\
\text { (range } 5-45 \mathrm{mg} / \text { day) } \\
\text { - Administered as a syrup } \\
\text { - } 95 \text { patients were aged } \\
0-5 \text { years and } 43 \text { patients } \\
\text { were aged 6-12 years }\end{array}$ & $\begin{array}{l}\text { Evaluation of efficacy } \\
\text { was based } \\
\text { on subjective } \\
\text { parameters of the } \\
\text { attending physician }\end{array}$ & $\begin{array}{l}\text { - Efficacy, rated as 'good' } \\
\text { or 'very good' in } 82.5 \% \\
\text { of the children, } \\
\text { was seen as early } \\
\text { as } 20 \text { min after } \\
\text { treatment but was } \\
\text { found to be } \\
\text { optimal at day } 3 \\
\text { - The investigators concluded } \\
\text { that ambroxol syrup was } \\
\text { effective for the treatment } \\
\text { of acute, sub-acute and chronic } \\
\text { respiratory diseases }\end{array}$ & $\begin{array}{l}\text { A child with endogenous } \\
\text { eczema (age unknown) } \\
\text { experienced allergic } \\
\text { exanthema on day } 6 \text { but } \\
\text { this did not lead to } \\
\text { discontinuation }\end{array}$ \\
\hline $\begin{array}{l}\text { Huizar } \\
\text { Lara } \\
\text { et al. [35] }\end{array}$ & $\begin{array}{l}\text { Open-label, } \\
\text { multicentre study } \\
\text { to assess efficacy } \\
\text { and safety } \\
\text { of ambroxol }\end{array}$ & $\begin{array}{l}\text { Patients aged } \\
2-12 \text { years with } \\
\text { acute and chronic } \\
\text { respiratory tract } \\
\text { infections (including } \\
\text { bronchial asthma, } \\
\text { bronchitis, } \\
\text { bronchopneumonia } \\
\text { and asthmatiform bronchitis }\end{array}$ & $\begin{array}{l}\text { - } 74 \text { patients received } \\
\text { ambroxol for } 7 \text { days } \\
\text { at dosages of } 30-45 \mathrm{mg} / \text { day } \\
\text { for children aged 6-12 years } \\
\text { and } 22.5 \mathrm{mg} / \text { day for } \\
\text { children aged 2-5 years, } \\
\text { with or without antibiotics } \\
\text { - Administered as oral solution }\end{array}$ & $\begin{array}{l}\text { Evaluation of } \\
\text { secretion viscosity, } \\
\text { sputum characteristics, } \\
\text { respiratory function } \\
\text { and radiographical } \\
\text { observations }\end{array}$ & $\begin{array}{l}\text { - The results obtained } \\
\text { for these parameters } \\
\text { were rated as 'excellent', } \\
\text { 'good' and 'unsatisfactory' } \\
\text { in } 83.7 \%, 15 \% \text { and } 1.3 \% \\
\text { of the children, respectively } \\
\text { - Ambroxol was reported } \\
\text { to have a significant } \\
\text { mucolytic effect }\end{array}$ & No side effects reported \\
\hline $\begin{array}{l}\text { Boehringer } \\
\text { Ingelheim } \\
\text { International } \\
\text { GmbH [36] }\end{array}$ & $\begin{array}{l}\text { Open-label, } \\
\text { observational } \\
\text { study }\end{array}$ & $\begin{array}{l}\text { Patients aged <2 } \\
\text { months-14 years with } \\
\text { acute or chronic bronchitis, } \\
\text { tracheobronchitis } \\
\text { or common cold }\end{array}$ & $\begin{array}{l}\text { - } 103 \text { children treated with } \\
\text { ambroxol for } 8 \text { days } \\
\text { - } 15 \mathrm{mg} / \text { day for children } \\
\text { up to } 2 \text { years; } 22.5 \mathrm{mg} / \text { day } \\
\text { for children } 2-5 \text { years; } \\
30-45 \mathrm{mg} / \text { day for } \\
\text { children }>5 \text { years }\end{array}$ & $\begin{array}{l}\text { - Disappearance of fever } \\
\text { and improvement } / \\
\text { disappearance of bronchial } \\
\text { signs and symptoms } \\
\text { - Efficacy scored according } \\
\text { to time taken for } \\
\text { improvements to become } \\
\text { apparent: } \\
\text { day } 4=\text { excellent, } \\
\text { day } 5=\text { very good, } \\
\text { day } 6=\text { good, } \\
\text { and day } 8=\text { moderate }\end{array}$ & $\begin{array}{l}\text { Efficacy of ambroxol was } \\
\text { rated as excellent in } 70(68 \%) \text {, } \\
\text { very good in } 15(14.6 \%) \text {, } \\
\text { good in } 13(12.6 \%) \text {, moderate } \\
\text { in } 1(1 \%) \text { and poor in } 4(3.9 \%) \\
\text { patients } \\
\text { Highest efficacy found } \\
\text { in children 0-2 months, } \\
\text { with a complete } \\
\text { disappearance of symptoms } \\
\text { after 4-6 days of treatment }\end{array}$ & No side effects reported \\
\hline
\end{tabular}


Table 3. Characteristics and results of real-world evidence studies of ambroxol as an over-the-counter secretolytic therapy.

$\begin{array}{ll}\text { Study } & \begin{array}{l}\text { Study design } \\ \text { and aim }\end{array} \\ \text { Kardos } & \text { Pharmacy-based survey } \\ \text { et al. } & \text { assessing differential } \\ {[37]} & \text { patient profiles } \\ & \text { and the efficacy } \\ & \text { of four ambroxol } \\ & \text { formulations } \\ & \text { (extended-release } \\ & \text { capsules, adult syrup, } \\ & \text { pediatric syrup and } \\ & \text { soft pastilles) }\end{array}$

Number of
patients
who purchased on
of the ambroxol
formulations

Study
parameters

Questionnaire comprised a patient-adapted version of the Bronchitis Severity Scale (BSS), questions on the degree of impairment by acute cough, time to onset of symptom relief, and duration of treatment. the pediatric syrup $(n=244)$ were entered by their parents Data on patients receiving

Efficacy results

- Treatment with ambroxol (all formulations) reduced BSS score by 5.5 points by the end of treatment. The strongest improvement was reported for chest pain while coughing $(-1.2 ; 75 \%)$, followed by rattles $(-1.2 ; 71 \%)$, dyspnea $(-0.9 ; 69 \%)$, cough $(-1.6 ; 57 \%)$ and sputum $(-0.8 ; 40 \%)$

- Improvements in BSS scores were similar between formulations; however, minor differences in favor of the pediatric syrup were observed [ $62 \%$ (pediatric syrup) versus 59\% (extended-release capsules and pastilles) and 5\%

5 (adult syrup)]

- Treatment with all formulations improved bronchitis-associated impairments in up to $60 \%$ of patients

- In $\geq 90 \%$ of the patients, the time to onset of symptom relief was less than 60 minutes. Symptomatic relief occurred most rapidly in patients receiving the pediatric syrup or pastilles ( $43.4 \%$ and $45.2 \%$ of users taking the pediatric syrup and pastilles, respectively, reported a time to onset of 15-30 minutes, whereas $47.8 \%$ and $42.1 \%$ of those taking the extended-release capsules and adult syrup, respectively, reported a time to onset of 30-60 min)

- The mean duration of treatment was $4.3 \pm 0.9$ days, with no obvious differences between formulations

$\begin{array}{ll}\text { Schulz } & \text { Community } \\ \text { et al. } & \text { pharmacy-based } \\ {[38]} & \text { cohort study } \\ & \text { assessing } \\ & \text { the tolerability, } \\ & \text { self-perceived } \\ & \text { effectiveness } \\ & \text { and usage pattern } \\ & \text { of ambroxol }\end{array}$

$\begin{array}{lll}2,664 \text { customers } & \text { Tolerability, } & \text { - Patients complied with } \\ \text { who bought } & \text { self-perceived } & \text { the recommended dosage and use, } \\ \text { ambroxol syrup } & \text { effectiveness } & \text { with only } 0.7 \% \text { of patients taking } \\ (12-95 \text { years } & \text { and usage pattern } & \text { the maximum daily dose } \\ \text { of age) } & \text { of ambroxol } & \text { - In total, } 92 \% \text { of patients rated } \\ & & \text { the self-perceived effectiveness } \\ & \text { as 'very good' (29\%) or 'good' (63\%) } \\ & \text { - } 89 \% \text { of patients were willing } \\ & \text { to purchase ambroxol syrup again }\end{array}$

Safety

results

- Patients rated the global tolerability of ambroxol as 'very good' (56.4\%), 'good' (41.2\%), 'moderate' (2.1\%) or 'poor' $(0.3 \%)$, with slightly better ratings reported for the pediatric syrup and pastilles - Despite the broad definition of an $\mathrm{AE}$ in this survey (any worsening of symptoms or condition-associated impairments), AEs were reported in only $10.3 \%$ of patients, none of which were considered serious - $91 \%$ of reported AEs were based on worsening of symptom or impairment scores

-67 patients (2.5\%) reported an $\mathrm{AE}$, none of which were serious or unexpected - The majority of AEs were mild and affected the gastrointestinal tract $(65 \%)$ or skin and subcutaneous tissue (11\%)

- The safety of ambroxol was rated as 'very good' (51\%) or 'good' (46\%) in $97 \%$ of patients 
resolved by day 3 [29]. Both treatments significantly improved expectoration and severity of cough $(\mathrm{p}<0.001)$; however, improvements in these symptoms occurred more rapidly with ambroxol (73.3\% free of symptoms on day 3 ) compared with SCMC (46.6\% free of symptoms on day 3) [29]. In addition, remission of auscultatory signs was significant at day 2 with ambroxol $(\mathrm{p}<0.02)$ compared with day 6 in the SCMC group $(\mathrm{p}<0.01)$ [29]. Overall, the physicians rated efficacy as 'excellent' for $50 \%$ of the ambroxol group compared with $25 \%$ for the SCMC group and 'good' for $50 \%$ of the ambroxol group compared with $75 \%$ of the SCMC group [29]. The authors concluded that, although no significant treatment difference between the two therapies was observed at the end of treatment, from a clinical perspective, the rapid improvement in clinical signs and symptoms following ambroxol treatment suggests ambroxol is superior to SCMC [29].

\section{Additional active-controlled studies}

Similarly to the study by Careddu and Zavattini [28], an activecontrolled study by Baldini et al. compared the efficacy of ambroxol and NAC in 28 children aged 2-13 years with acute spastic bronchitis [30]. In total, 14 children received $30 \mathrm{mg} /$ day ambroxol for 10 days (28). Efficacy was assessed by changes in sputum characteristics, bronchial sounds, cough, difficulty expectorating sputum and dyspnea (28). Both treatments improved all bronchial signs and symptoms; however, by Day 5, these improvements occurred more rapidly in the ambroxol group compared with the NAC group. Additionally, changes in dyspnea were significantly greater with ambroxol than NAC $(\mathrm{p}<0.05)[30]$.

Two open-label studies compared the efficacy of ambroxol and sobrerol in 80 children aged 1 month-12 years with acute bronchitis and bronchopneumonia [31,32]. Ambroxol was administered intramuscularly daily for 6-10 days at the following dosages: 1.7 $\mathrm{mg} / \mathrm{kg}$ (children $<2$ years), $1.6 \mathrm{mg} / \mathrm{kg}$ (children $2-5$ years) and 1.2 $\mathrm{mg} / \mathrm{kg}$ (6-10 years). The efficacy of ambroxol was assessed using changes in cough, dyspnea and auscultatory signs. In these studies, 'excellent' efficacy was reported by the physician in 50\% [31] and $65 \%$ [32] of patients in the ambroxol group compared with $45 \%$ [31] and 25\% [32] in the sobrerol group; corresponding values for 'good' efficacy were $40 \%$ and $25 \%$ in the ambroxol group and $35 \%$ and $45 \%$ in the sobrerol group $[31,32]$.

\section{Uncontrolled clinical studies}

The dose-response relationship and benefit/risk profile of different ambroxol formulations in children was investigated in a study by Weinmann [33], involving 642 children aged 2 months15 years with acute and chronic airway diseases (mainly bronchitis) [33]. In the study investigating ambroxol as a syrup, an 'original formulation' and a 'final formulation' were administered to 340 children aged 2 months- 14 years (original formulation, $n=229$ children; final formulation, $\mathrm{n}=111$ ). Both formulations contained the same concentration of ambroxol but differed slightly in excipients [33]. For the original formulation, children aged $<2$ years, 2-5 years and 6-12 years received 15-20, 25-30 and $45 \mathrm{mg}$ /day, respectively, for 5-7 days. Some children also received antibiotics [33]. In children with sputum, a mucolytic effect was reported on day 2 or 3 of treatment. Additionally, cough present at baseline improved or disappeared completely in $87 \%$ of patients by day 7 [33]. Thus, the benefit/risk profile of ambroxol was deemed highly favorable as symptoms completely resolved or improved after 7 days of treatment in all age groups [33]. The 'final formulation' was administered in two single doses of $15 \mathrm{mg}$ /day (children aged $<2$ years) or $30 \mathrm{mg} /$ day (children aged $>2$ years) [33]. Similarly to the 'original formulation', the therapeutic effect of ambroxol was evident in the majority (81\%) of children after 2-3 days of treatment [33]. Additionally, from day 3 there was a substantial improvement in sputum volume and by day 7 , sputum and dry cough were absent in >two thirds of patients (33).

In an open-label, multicenter study involving 137 children with acute, sub-acute and chronic upper respiratory tract disorders (mainly bronchitis), children aged 0-12 years received 5-45 mg ambroxol daily for up to 28 days [343]. Efficacy, rated as 'good' or 'very good' in $82.5 \%$ of the children by the attending physician (according to subjective parameters), was seen as early as $20 \mathrm{~min}$ post-treatment and was found to be optimal at day 3 [34]. The investigators concluded that ambroxol syrup was effective for the treatment of acute, sub-acute and chronic respiratory diseases [34].

In another open-label, multicenter study by Huizar Lara et al. [35], ambroxol oral solution was administered at dosages of 30-45 $\mathrm{mg}$ /day (children aged 6-12 years) and $22.5 \mathrm{mg} /$ day (children aged 2-5 years) for 7 days, with or without bronchodilators or antibiotics [35]. This study included 74 children with acute and chronic respiratory tract infections, including bronchial asthma, bronchitis, bronchopneumonia and asthmatiform bronchitis [35]. Efficacy was assessed by evaluating sputum characteristics, respiratory function and radiographical observations [35]. The results obtained for these parameters were rated as 'excellent', 'good' and 'unsatisfactory' in $83.7 \%, 15 \%$ and $1.3 \%$ of the children, respectively, following ambroxol treatment [35]. Subsequently, ambroxol was reported to have a significant mucolytic effect [35].

In an open-label, observational study, 103 children aged $<2$ months-14 years with acute or chronic bronchitis, tracheobronchitis or common cold were treated with ambroxol for 8 days [36]. Children $\leq 2$ years, 2-5 years and $>5$ years were given ambroxol at dosages of $15,22.5$ and $30-45 \mathrm{mg} /$ day, respectively [36]. Treatment effects were assessed at days 2, 4, 6 and 8; these were measured by disappearance of fever and improvement or disappearance of bronchial signs and symptoms [36]. Efficacy was scored according to the time taken for improvements to become apparent: day $4=$ excellent, day $5=$ very good, day $6=$ good, and day $8=$ moderate. No improvement was characterized as 'poor' [36]. Overall, the efficacy of ambroxol was rated as 'excellent' in $68 \%$, 'very good' in $14.6 \%$, 'good' in $12.6 \%$, 'moderate' in $1 \%$ and 'poor' in $3.9 \%$ of patients [36]. Children aged 0-2 months had the greatest efficacy, with a complete disappearance of bronchial symptoms 4-6 days following ambroxol treatment [36].

\section{Cohort studies and surveys}

In a pharmacy-based survey involving 941 customers, differential patient profiles and the efficacy of four ambroxol formulations (extended-release capsules, adult syrup, pediatric syrup and soft pastilles) were investigated [37]. Customers who purchased one of the ambroxol formulations completed a questionnaire comprising a patient-adapted version of the Bronchitis Severity Scale (BSS), questions on the degree of impairment by acute cough, time to onset of symptom relief, and duration of treatment [37]. Data on patients receiving the pediatric syrup $(n=244)$ were entered by their parents [37]. Treatment with ambroxol (all formulations) reduced the BSS score by 5.5 points by the end of treatment. The strongest improvement was reported for chest pain while coughing $(-1.2 ; 75 \%)$, followed by rattles $(-1.2 ; 71 \%)$, dyspnea $(-0.9 ; 69 \%)$, cough $(-1.6 ; 57 \%)$ and sputum $(-0.8 ; 40 \%)$. Improvements in BSS scores were similar between formulations; however, minor differences in favor of the pediatric syrup were observed [ $62 \%$ (pediatric syrup) versus $59 \%$ (extended-release capsules and pastilles) and $55 \%$ (adult syrup)] [37]. Treatment with all formulations improved bronchitis-associated impairments in up to $60 \%$ of patients. In $\geq 90 \%$ of the patients, the time to onset of symptom relief was less than 60 minutes. Symptomatic relief occurred most rapidly in patients receiving the pediatric syrup or pastilles $(43.4 \%$ and $45.2 \%$ of users taking the pediatric syrup and pastilles, respectively, reported a time to onset of $15-30 \mathrm{~min}$, whereas $47.8 \%$ and $42.1 \%$ of those taking the extended-release capsules and adult 
syrup, respectively, reported a time to onset of 30-60 min) [37]. The mean duration of treatment was $4.3 \pm 0.9$ days, with no obvious differences between formulations [37].

In a community pharmacy-based cohort study, customers who bought ambroxol syrup completed a questionnaire, providing data on tolerability, self-perceived effectiveness and usage pattern of ambroxol [38]. In total, 2,664 questionnaires were evaluable, completed by patients aged 12-95 years [38]. Overall, patients complied with the recommended dosage and use, with only $0.7 \%$ of patients taking the maximum daily dose [38]. In total, $92 \%$ of patients rated the self-perceived effectiveness as 'very good' $(29 \%)$ or 'good' $(63 \%)$, with $89 \%$ of patients willing to purchase ambroxol syrup again [38].

\section{Safety overview}

\section{Controlled clinical studies}

Ambroxol was considered well tolerated in children aged 0-12 years in the controlled studies presented in this review, with no AEs reported that were directly attributed to the treatment [27-32]. The study by Careddu and Zavattini [28] reported that ambroxol was equally well tolerated irrespective of age, and that the systemic tolerability of ambroxol was good as no changes in laboratory results were observed between the start and end of treatment [28]. This is supported by the findings from the other controlled studies included in this review, in which no adverse changes in laboratory findings occurred following ambroxol treatment [27,29-32].

\section{Uncontrolled clinical studies}

Consistent with the findings from the controlled studies, the four uncontrolled studies presented also reported ambroxol to be well tolerated by children [33-36]. However, in contrast, several AEs were reported, including facial erythema $(n=1)$, dermatitis $(n=1)$, vomiting $(n=2)$, cutaneous rash due to totocillin $(n=1)$, headache $(n=1)$, mild fatigue $(n=1)$, diarrhea $(n=3)$ and allergic exanthema $(n=1)[33,34]$. In addition, in one study, a child with endogenous eczema (age unspecified) receiving ambroxol syrup experienced allergic exanthema on day 6 of treatment; however, this did not lead to treatment discontinuation [34]. We must note that the majority of these AEs were reported following the use of less frequently used formulations of ambroxol (i.e. tablets, drops/inhalant solution or intramuscular injection) and were predominantly deemed unrelated to ambroxol by the investigators $[33,34]$. Furthermore, no AEs were reported in two of the four uncontrolled studies discussed in this review $[35,36]$.

\section{Cohort studies and surveys}

In the survey by Kardos et al. [37], patients rated the global tolerability of ambroxol as 'very good' (56.4\%), 'good' (41.2\%), 'moderate' $(2.1 \%)$ or 'poor' $(0.3 \%)$, with slightly better ratings reported for the pediatric syrup and pastilles [37]. Despite the broad definition of an AE in this survey (any worsening of symptoms or condition-associated impairments), AEs were reported in only $10.3 \%$ of patients, none of which were considered serious. Overall, $91 \%$ of reported AEs were based on worsening of symptom or impairment scores [37]. In the cohort study by Schulz et al. [38], only 67 patients $(2.5 \%)$ reported an AE, none of which were serious or unexpected. The majority of AEs were mild and affected the gastrointestinal tract $(65 \%)$ or skin and subcutaneous tissue $(11 \%)$ [38]. The safety of ambroxol was rated as 'very good' $(51 \%)$ or 'good' $(46 \%)$ in $97 \%$ of patients [38].

\section{Safety of ambroxol in acute respiratory distress syndrome (ARDS)}

Zhang et al. [12] evaluated the efficacy and safety of antenatal ambroxol as a preventative therapy for RDS in preterm infants in a review of 12 randomized controlled studies involving 1,335 premature infants [12]. Eight of these studies reported AEs, which included nausea, vomiting, chest tightness and mild tachycardia, all of which improved or were more tolerable following a reduction of the dosage drip rate [12]. None of the AEs led to treatment discontinuation and no study reported AEs affected the fetus or neonate [12]. Additionally, a prospective, randomized, placebo-controlled, blinded pilot study by Baranwal et al. [39], involving 66 mechanically ventilated patients (aged 1 month-12 years), evaluated the efficacy of high-dose oral ambroxol in ARDS [39]. In this study, no AEs were reported following ambroxol treatment [39].

\section{Discussion}

The clinical studies included in this review, comprising almost 1,300 pediatric patients, report strong clinical outcomes following the use of ambroxol as a secretolytic agent [27-36]. Furthermore, the efficacy and safety of ambroxol was found to be consistent in all age groups. Ambroxol was considered well tolerated in all of the studies presented, thus, the efficacy and safety of ambroxol in children appears to be analogous to that reported for adults [13].

In the active-controlled studies included in this review, it is suggested that the efficacy of ambroxol is, at a minimum, non-inferior to that of NAC, SCMC and sobrerol. Ambroxol was reported to be more effective at relieving symptoms and signs of acute and chronic respiratory disease, and to have a more rapid onset of action [28-32]. It is also evident from the study by Principi et al. [27] that ambroxol could be working synergistically with antibiotics, resulting in faster symptom relief compared with treatment with antibiotics alone [27]. Recent evidence on the anti-biofilm activity of ambroxol suggests ambroxol may be a new therapeutic option in preventing major biofilm-dependent airway infections, such as ventilator-associated pneumonia, cystic fibrosis and chronic obstructive pulmonary disease, which are currently difficult to treat due to antibiotic resistance [40]. Ambroxol disrupts the structural integrity of bacterial biofilms, as measured by scanning electron microscopy, which showed that the biofilm of Pseudomonas aeruginosa (produced in vitro) was thinner and fragmented following 7 days of ambroxol exposure compared with that formed in control conditions [40]. These findings support previous data reported by Principi et al. [27]. which demonstrated ambroxol's synergistic action in combination with antibiotics.

The RWE data presented, representing a total of 3,629 patients (including over 244 children), provides an insight into the favorable efficacy and safety of ambroxol as a non-prescription medication in a heterogeneous population within a real-life, day-to-day setting, for which the product was originally intended. In the survey by Kardos et al. [37], ambroxol rapidly reduced BSS scores and improved bronchitis-associated impairments. In this survey, very few AEs were reported and almost all patients (97\%) rated the global tolerability of ambroxol as 'good' or 'very good' [37]. Very similar findings were reported in the study by Schulz et al. [38]. These data support the role of ambroxol as safe and effective OTC secretolytic therapy.

Following a benefit/risk assessment by the European Medicines Agency's Pharmacovigilance Risk Assessment Committee (PRAC) in 2014, it was reported that ambroxol is associated with a small risk of hypersensitivity reactions, including anaphylactic reactions and severe cutaneous adverse reactions 
(SCARs) [8]. Thus, the PRAC concluded that, subject to updating the product information to include the small risk of hypersensitivity reactions, the overall benefit/risk profile of ambroxol remains favorable in all age groups and for all indications [8]. The product information (SMPC) was subsequently updated.

Furthermore, in a review by Zhang et al. [12] no adverse effects on fetuses or neonates were reported following ambroxol treatment [12]. Additionally, high-dose ambroxol treatment did not cause any AEs in children aged 1 month-12 years with ARDS in the study by Baranwal et al. [39]. These findings further emphasize the favorable safety profile of ambroxol (regardless of indication), even in early infancy.

Ambroxol was reported to be well tolerated in all studies included in this review and, in most studies, no ambroxol-related side effects were reported [27-36]. In addition, side effects known to be associated with ambroxol treatment, such as gastrointestinal disturbances and cutaneous rash, occurred rarely and represented isolated cases. Furthermore, in the studies in which laboratory tests were performed, no adverse changes were observed following ambroxol treatment, suggesting no clinically relevant adverse effects occurred. When brought together, these findings suggest that ambroxol has a good safety profile in children aged $0-12$ years with acute and chronic respiratory diseases.

As the data reviewed here were mostly obtained from clinical studies conducted some decades ago, and before the introduction of GCP, the findings of this review could be reinforced by conducting further controlled studies of ambroxol, in children, that adhere to the GCP guidelines. Although the focus of this review was the secretolytic indication of ambroxol, particularly in the OTC setting, this review also highlights new potential therapeutic roles for ambroxol in ARDS and biofilm-dependent airway infections.

\section{Conclusions}

The evidence collected from the studies presented here supports the opinion that ambroxol is both efficacious and tolerable as a non-prescription, secretolytic therapy for children with acute and chronic respiratory diseases. Due to the continual safety monitoring of ambroxol in pediatric patients, considerable documentation exists, that supports the favorable benefit/risk profile of ambroxol in adults and children of all ages, starting from neonates, with acute and chronic respiratory diseases.

\section{Acknowledgments}

The authors would like to acknowledge Evie Lambert BSc, of iMed Comms, an Ashfield Company, part of UDG Healthcare plc for medical writing support that was funded by Sanofi in accordance with Good Publications Practice (GPP3) guidelines (http://www.ismpp.org/gpp3).

$\begin{array}{ll}\text { Abbreviations } & \\ \text { OTC } & \begin{array}{l}\text { over the counter } \\ \text { infant respiratory distress syndrome } \\ \text { IRDS }\end{array} \\ \text { RDS } & \text { respiratory distress syndrome } \\ \text { PRAC } & \text { Pharmacovigilance Risk Assessment Committee } \\ \text { SCAR } & \text { real world evidence } \\ \text { RWE } & \text { adverse event } \\ \text { AE } & \text { Good Clinical Practice } \\ \text { GCP } & \text { N-acetylcysteine }\end{array}$

$\begin{array}{ll}\mathrm{FEV}_{1} & \text { forced expiratory volume in } 1 \text { second } \\ \mathrm{MEF}_{25} & \begin{array}{l}\text { maximal expiratory flow at } 25 \% \text { of forced } \\ \text { vital capacity }\end{array} \\ \text { Rawt } & \text { total airway resistance } \\ \text { SCMC } & \text { S-carboxymethyl cysteine } \\ \text { BSS } & \text { Bronchitis Severity Scale } \\ \text { ARDS } & \text { acute respiratory distress syndrome }\end{array}$

\section{References}

1. Morice A, Kardos P. Comprehensive evidence-based review on European antitussives. BMJ Open Respir Res 2016;3:e00137.

2. Braman SS. Chronic cough due to acute bronchitis: ACCP evidence-based clinical practice guidelines. Chest 2006;S129:95103.

3. Thompson M, Cohen HD, Vodicka TA, Blair PS, Buckley DI, Henegan $\mathrm{C}$, et al. Duration of symptoms of respiratory tract infections in children: systematic review. BMJ 2013; 347:f7027.

4. Chang AB, Glomb WB. Guidelines for evaluating chronic cough in pediatrics: ACCP evidence-based clinical practice guidelines. Chest 2006;129:S260-83.

5. Schroeder K, Fahey T. Should we advise parents to administer over the counter cough medicines for acute cough? Systematic review of randomised controlled trials. Arch Dis Child 2002;86:170-5.

6. Smith SM, Schroeder K, Fahey T. Over-the-counter (OTC) medications for acute cough in children and adults in community settings. Cochrane Database Syst Rev 2014:CD001831.

7. Balsamo R, Lanata L, Egan CG. Mucoactive drugs. Eur Respir Rev 2010;19:127-33.

8. European Medicine Agencies. Revised assessment report: Ambroxol and bromhexine containing medicinal products 2015. Available from: https://www.ema.europa.eu/en/documents/referral/ambroxol-bromhexine-article-31-referral-pracassessment-report_en.pdf

9. Zanasi A, Mazzolini M, Kantar A. A reappraisal of the mucoactive activity and clinical efficacy of bromhexine. Multidiscip Respir Med 2017;12:7.

10. Gupta PR. Ambroxol - Resurgence of an old molecule as an anti-inflammatory agent in chronic obstructive airway diseases. Lung India 2010;27:46-8.

11. Paleari D, Rossi GA, Nicolini G, Olivieri D. Ambroxol: a multifaceted molecule with additional therapeutic potentials in respiratory disorders of childhood. Expert Opin Drug Discov 2011;6:1203-14.

12. Zhang ZQ, Wu QQ, Huang XM, Lu H. Prevention of respiratory distress syndrome in preterm infants by antenatal ambroxol: a meta-analysis of randomized controlled trials. Am J Perinatol 2013;30:529-36.

13. Cazan D, Klimek L, Sperl A, Plomer M, Kolsch S. Safety of ambroxol in the treatment of airway diseases in adult patients. Expert Opin Drug Saf 2018;17:1211-24.

14. Sanofi-Aventis. Ambroxol - Summary of Product Characteristics 2019. Available from: https://www.mucosolvan.de

15. Disse BG. The pharmacology of ambroxol -review and new results. Eur J Respir Dis Suppl 1987;153:255-62.

16. Fois G, Hobi N, Felder E, Ziegler A, Miklave P, Walther P, et al. A new role for an old drug: Ambroxol triggers lysosomal exocytosis via $\mathrm{pH}$-dependent $\mathrm{Ca}(2)(+)$ release from acidic $\mathrm{Ca}(2)(+)$ stores. Cell Calcium 2015;58:628-37.

17. Glowania A MR, Böhm M, Knopf A, Klimek L. The surfactant system - a new approach for treating the upper respiratory tract 
mucosa. Atemwegs Lungenkrankh 2011;37:S1-5.

18. K Morgenroth JB. Morphological features of the interaction between mucus and surfactant on the bronchial mucosa. Respiration 1985;47:225-31.

19. Disse BG, Ziegler HW. Pharmacodynamic mechanism and therapeutic activity of ambroxol in animal experiments. Respiration 1987;51:S15-22.

20. Hasegawa I, Niisato N, Iwasaki Y, Marunaka Y. Ambroxolinduced modification of ion transport in human airway Calu-3 epithelia. Biochem Biophys Res Commun 2006;343:475-82.

21. Muroi Y, Undem BJ. Targeting voltage gated sodium channels $\mathrm{NaV1.7,} \mathrm{Na} \mathrm{V1.8,} \mathrm{and} \mathrm{Na} \mathrm{V1.9} \mathrm{for} \mathrm{treatment} \mathrm{of} \mathrm{pathological}$ cough. Lung 2014;192:15-20.

22. Yang B, Yao DF, Ohuchi M, Ide M, Yano M, Okumura Y, et al. Ambroxol suppresses influenza-virus proliferation in the mouse airway by increasing antiviral factor levels. Eur Respir J 2002;19:952-8.

23. Li F, Yu J, Yang H, Wan Z, Bai D. Effects of ambroxol on alginate of mature Pseudomonas aeruginosa biofilms. Curr Microbiol 2008;57:1-7.

24. Deretic V, Timmins GS. Enhancement of lung levels of antibiotics by ambroxol and bromhexine. Expert Opin Drug Metab Toxicol 2019;15:213-8.

25. Basabe-Burgos O, Zebialowicz J, Stichtenoth G, Curstedt T, Bergman $\mathrm{P}$, Johansson $\mathrm{J}$, et al. Natural derived surfactant preparation as a carrier of polymyxin $\mathrm{E}$ for treatment of Pseudomonas aeruginosa pneumonia in a near-term rabbit model. J Aerosol Med Pulm Drug Deliv 2019;32:110-8.

26. Vijayananthan A, Nawawi O. The importance of good clinical practice guidelines and its role in clinical trials. Biomed Imaging Interv J 2008;4:e5.

27. Principi N, Zavattini G, Daniotti S. Possibility of interaction among antibiotics and mucolytics in children. Int $\mathrm{J}$ Clin Pharmacol Res 1986;6:369-72.

28. Careddu P, Zavattini G. Mucosolvan ${ }^{\circledR}$ (Ambroxol) in paediatric use - Controlled clinical trial vs. acetylcysteine. Asthma Bronch Emphys 1984;4:23-26.
29. Berni M, Collina A, Zavattini G. [Ambroxol in bronchopulmonary pathology in children].[Article in Italian]. Clin Ter 1983;106:351-5.

30. Baldini G, Gucci M, Tarò D, Memmini C. [Controlled clinical study of a new ambroxol formulation in the treatment of infantile spastic bronchitis in children].[Article in Italian]. Min Ped 1989;41:91-5.

31. Boehringer Ingelheim International GmbH. Data on file (U860347). 1983.

32. Boehringer Ingelheim International GmbH. Data on file (U860348). 1983.

33. Weinmann HM. Ambroxol (Mucosolvan) in paediatrics. Clinical results with different forms of administration. Therapiewoche 1981;31:7940-7.

34. Boehringer Ingelheim International GmbH. Data on file (U750124). 1985.

35. Huizar Lara H, Ortega Guzman S, Quiroga Garza S. [Ambroxol, a new bronchosecretolytic in paediatric bronchopulmonary conditions].[Article in Spanish]. Invest Med Int 1985;11:83-90.

36. Boehringer Ingelheim International GmbH. Data on file (U840264). 1983.

37. Kardos P, Beeh KM, Sent U, Mueck T, Grater H, Michel MC. Characterization of differential patient profiles and therapeutic responses of pharmacy customers for four ambroxol formulations. BMC Pharmacol Toxicol 2018;19:40.

38. Schulz M, Hammerlein A, Hinkel U, Weis G, Gillissen A. Safety and usage pattern of an over-the-counter ambroxol cough syrup: a community pharmacy-based cohort study. Int J Clin Pharmacol Ther 2006;44:409-21.

39. Baranwal AK, Murthy AS, Singhi SC. High-dose oral ambroxol for early treatment of pulmonary acute respiratory distress syndrome: an exploratory, randomized, controlled pilot trial. J Trop Pediatr 2015;61:339-50.

40. Cataldi M, Sblendorio V, Leo A, Piazza O. Biofilm-dependent airway infections: a role for ambroxol? Pulm Pharmacol Ther 2014;28:98-108.

Received for publication: 15 October 2019. Accepted for publication: 14 February 2020.

This work is licensed under a Creative Commons Attribution-NonCommercial 4.0 International License (CC BY-NC 4.0).

CCopyright: the Author(s), 2020

Licensee PAGEPress, Italy

Multidisciplinary Respiratory Medicine 2020; 15:511

doi:10.4081/mrm.2020.511 